\title{
Laboratory Report on the Removal of Pertechnetate from Tank 241-AN-105 Simulant using Purolite A530E
}

\section{J. B. Duncan}

Washington River Protection Solutions LLC

K. J. Hagerty

AREVA Federal Services

W. P. Moore

J. M. Johnson

RJ Lee Group

Date Published

June 2012

Prepared for the U.S. Department of Energy

Office of River Protection

Contract No. DE-AC27-08RV14800 


\section{LAB-RPT-12-00002 R1}

\section{EXECUTIVE SUMMARY}

This effort falls under the technetium management initiative and will provide data for those who will make decisions regarding the handling and disposition of technetium. To that end, the objective of this effort is to challenge Purolite ${ }^{\circledR 1}$ A530E against a double-shell tank simulant from tank 241-AN-105 spiked with pertechnetate $\left(\mathrm{TcO}_{4}{ }^{-}\right)$.

The Purolite ${ }^{\circledR}$ A530E is commercially available and is currently being used at the $200 \mathrm{West}$ Pump and Treat Groundwater Treatment Plant to remove pertechnetate. It has been demonstrated that Purolite ${ }^{\circledR} \mathrm{A} 530 \mathrm{E}$ is highly effective in removing $\mathrm{TcO}_{4}{ }^{-}$from a water matrix. Purolite ${ }^{\circledR}$ A530E is the commercial product of the Oak Ridge National Laboratory's Biquat ${ }^{\text {TM }}$ resin. Further work has demonstrated that technetium-loaded A530E achieves a leachability index in Cast Stone of 12.5 (RPP-RPT-39195, Assessment of Technetium Leachability in Cement-Stabilized Basin 43 Groundwater Brine).

When the batch contacted with various dilutions of spiked simulant from tank 241-AN-105, the Purolite ${ }^{\circledR}$ A530E resin demonstrated the following distribution coefficients $\left(\mathrm{K}_{\mathrm{d}}\right)$ :

\section{Distribution Coefficients as a Function of Sodium Molarity.}

\begin{tabular}{|c|c|}
\hline Tank 241-AN-105 [Na] & $\begin{array}{c}\text { Distribution Coefficient }\left(\mathbf{K}_{\mathbf{d}}\right) \\
\mathbf{m L} / \mathbf{g}\end{array}$ \\
\hline 5 & 2300 \\
\hline 7.5 & 1987 \\
\hline 10 & 984 \\
\hline
\end{tabular}

Following the batch contact, continuous flow column tests were conducted to determine breakthrough $\left(\mathrm{C} / \mathrm{C}_{0}=0.5\right)$. The tank $241-\mathrm{AN}-105$ simulant was adjusted to $6.5 \mathrm{M}$ sodium and spiked to $15.75 \mathrm{mg} / \mathrm{L}$ of pertechnetate (ORP-11242, River Protection Project System Plan). Two columns in series were used in a lead-lag configuration. The flow rate through the columns was $2 \mathrm{BV} / \mathrm{hr}$.

Breakthrough, $\mathrm{C} / \mathrm{C}_{0}=0.50$, occurred at $284 \mathrm{BV}$ for the lead column, and $\mathrm{C} / \mathrm{C}_{0}=0.98$ occurred at $342 \mathrm{BV}$, when the experiment was halted. The guard column reached a $\mathrm{C} / \mathrm{C}_{0}=0.01$ and maintained that value throughout the experiment. The column runs were halted when the pertechnetate spike simulant was depleted.

There was no visible degradation of the resin during the flow of approximately $171 \mathrm{hr}$.

The Purolite ${ }^{\circledR}$ A530E resin is a viable candidate for treating tank supernate in the 5.5 to $6.5 \mathrm{M}$ sodium range for the removal of the pertechnetate ion.

\footnotetext{
${ }^{1}$ Purolite is a registered trademark of Brotech Corporation, Bala Cynwyd, Pennsylvania.

${ }^{2}$ Biquat is a trademark of UT-Battelle LLC, Oak Ridge, Tennessee.
} 


\section{Table of Contents}

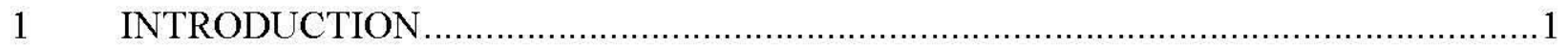

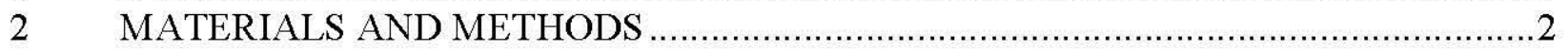

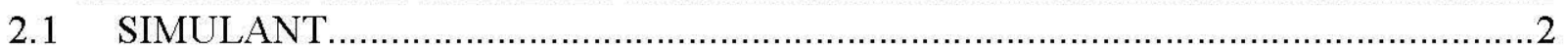

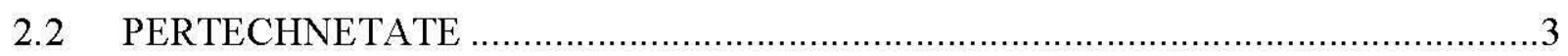

2.3 DISTRIBUTION COEFFICIENT DETERMINATION …...........................................4

$2.4 \quad$ PUROLITE $^{\circledR}$ A530E ION EXCHANGE RESIN ….....................................................

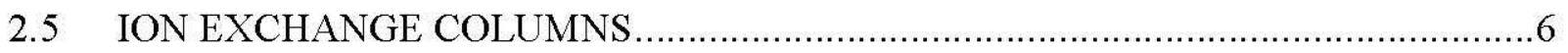

$3 \quad$ RESULTS

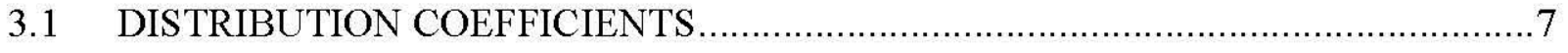

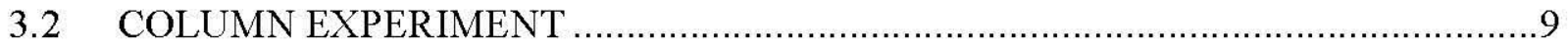

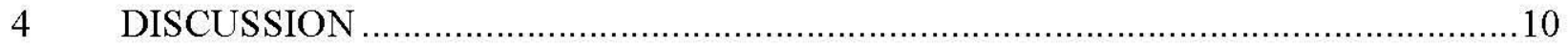

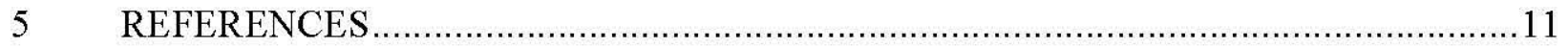

APPENDIX A Lead Column Response ………….................................................... A-i

\section{List of Tables}

Table 1. Tank 241-AN-105 Double-Shell Tank Simulant Chemical Makeup (1 L Batch), ..........2

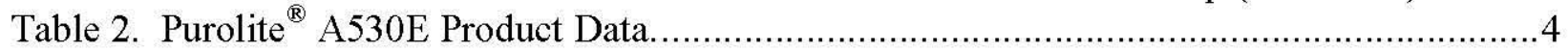

Table 3. Distribution Coefficients for Tank 241-AN-105....................................................

Table 4. Lambda Calculated Bed Volumes to Breakthrough $\left(\mathrm{C} / \mathrm{C}_{0}=0.5\right) \ldots \ldots \ldots \ldots \ldots \ldots \ldots \ldots \ldots \ldots \ldots . . .8$

\section{List of Figures}

Figure 1. Calibration Curve with Ludlum Model 2929 Dual Scaler. ..........................................

Figure 2. Purolite A530E at Time Zero in $10 \mathrm{M}$ Sodium Simulant..........................................

Figure 3. Purolite A530E at 7 Days in $10 \mathrm{M}$ Sodium Simulant. ............................................

Figure 4. Purolite A530E at 24 Days in 10 M Sodium Simulant. .........................................

Figure 5. Distribution Coefficients versus Contact Time......................................................

Figure 6. Pertechnetate Sorbed onto A530E from AN-105 Simulant at 6.5 M Sodium................

Figure 7. Column Test Configuration. ......................................................................

Figure 8. Breakthrough Curve for the Lead Column. ......................................................... 10 


\section{LAB-RPT-12-00002 R1}

\section{List of Terms}

\section{Abbreviations}

$\begin{array}{ll}\mathrm{AN}-105 & \text { tank 241-AN-105 } \\ \mathrm{C} / \mathrm{C}_{\mathrm{o}} & \text { column effluent concentration/column influent concentration } \\ \mathrm{DST} & \text { double-shell tank } \\ \text { ICP-MS } & \text { inductively coupled plasma-mass spectrometer } \\ \mathrm{K}_{\mathrm{d}} & \text { distribution coefficient } \\ \text { LAW } & \begin{array}{l}\text { low-activity waste } \\ \rho\end{array} \\ \text { density }\end{array}$

\section{Units}

$\begin{array}{ll}\text { BV } & \text { bed volume } \\ \mathrm{cm} & \text { centimeter } \\ \mathrm{g} & \text { gram } \\ \mathrm{hr} & \text { hour } \\ \mathrm{L} & \text { liter } \\ \mu \mathrm{m} & \text { micrometer } \\ \mathrm{M} & \text { molar } \\ \mathrm{MeV} & \text { million electron volts } \\ \mathrm{mg} & \text { milligrams }\end{array}$




\section{LAB-RPT-12-00002 R1}

\section{INTRODUCTION}

This report documents the laboratory testing and analyses as directed under the test plan, LAB-PLN-11-00010, Evaluation of Technetium Ion Exchange Material against Hanford Double Shell Tank Supernate Simulate with Pertechnetate.

Technetium (Tc-99) is a major fission product from nuclear reactors, and because it has few applications outside of scientific research, most of the technetium will ultimately be disposed of as nuclear waste. The radioactive decay of Tc-99 to ruthenium $99(\mathrm{Ru}-99)$ produces a low energy $\beta^{-}$particle $(0.1 \mathrm{MeV} \max )$. However, due to its fairly long half-life $\left(\mathrm{t}_{1 / 2}=2.13 \mathrm{E} 05\right.$ years $)$, Tc-99 is a major source of radiation in low-level waste (UCRL-JRNL-212334, Current Status of the Thermodynamic Data for Technetium and its Compounds and Aqueous Species).

Technetium forms the soluble oxy anion, $\mathrm{TcO}_{4}{ }^{-}$under aerobic conditions. This anion is very mobile in groundwater and poses a health risk (ANL, Radiological and Chemical Fact Sheets to Support Health Risk Analyses for Contaminated Areas).

It has been demonstrated that Purolite ${ }^{\circledR}$ A530E is highly effective in removing $\mathrm{TcO}_{4}{ }^{-}$from a water matrix (RPP-RPT-23199, The Removal of Technetium-99 from the Effluent Treatment Facility Basin 44 Waste Using Purolite A-530E, Reillex HPQ, and Sybron IONAC SR-7 Ion Exchange Resins). Purolite ${ }^{\circledR}$ A530E is the commercial product of the Oak Ridge National Laboratory's Biquat ${ }^{\mathrm{TM}}$ resin $(\mathrm{Gu}, \mathrm{B}$. et. al, "Development of Novel Bifunctional Anion-Exchange Resins with Improved Selectivity for Pertechnetate Sorption from Contaminated Groundwater"). Further work has demonstrated that technetium-loaded A530E achieves a leachability index in Cast Stone of 12.5 (ANSI/ASN-16.1-2003, Measurement of the Leachability of Solidified LowLevel Radioactive Wastes by a Short-term Test Procedure) as reported in RPP-RPT-39195, Assessment of Technetium Leachability in Cement-Stabilized Basin 43 Groundwater Brine.

This effort falls under the technetium management initiative and will provide data for those who will make decisions on the handling and disposition of technetium. To that end, the objective of this effort was to challenge Purolite ${ }^{\circledR}$ A530E against a double-shell tank (DST) simulant (tank 241-AN-105 or AN-105) spiked with pertechnetate $\left(\mathrm{TcO}_{4}{ }^{-}\right)$to determine breakthrough of the lead column.

Unless otherwise noted, all testing was conducted at ambient temperature and pressure conditions. 


\section{MATERIALS AND METHODS}

\subsection{SIMULANT}

Envelope A (DE-AC27-01RV14136, M147, Waste Treatment Plant Contract, "Statement of Work"), which is also known as Double-Shell Slurry Feed or Double-Shell Slurry, was chosen because it is an alkaline $\left(\left[\mathrm{OH}^{-}\right]>1 \mathrm{M}\right)$, high sodium $(>8 \mathrm{M})$ supernate. The envelope contains ${ }^{137} \mathrm{Cs}$ and ${ }^{99} \mathrm{Tc}$ at concentrations that require removal prior to low-activity waste (LAW) vitrification. The removal of $\mathrm{Sr} / \mathrm{TRU}$ is not required for this waste. The $\mathrm{AN}-105$ supernate recipe reported in WSRC-TR-2000-00338, Hanford Waste Simulants Created to Support the Research and Development on the River Protection Project - Waste Treatment Plant, was formulated and spiked with $15 \mathrm{mg} / \mathrm{L}$ of ${ }^{99} \mathrm{Tc}$. Table 1 shows the simulant recipe.

Table 1. Tank 241-AN-105 Double-Shell Tank Simulant Chemical Makeup (1 L Batch).

\begin{tabular}{|l|l|c|}
\hline \multicolumn{1}{|c|}{ Reagent } & \multicolumn{1}{|c|}{ Formula } & g/L \\
\hline Boric Acid & $\mathrm{H}_{3} \mathrm{BO}_{3}$ & 0.292 \\
\hline Cadmium Nitrate & $\mathrm{Cd}\left(\mathrm{NO}_{3}\right)_{2} \bullet 4 \mathrm{H}_{2} \mathrm{O}$ & 0.009 \\
\hline Calcium Nitrate & $\mathrm{Ca}\left(\mathrm{NO}_{3}\right)_{2} \bullet 4 \mathrm{H}_{2} \mathrm{O}$ & 0.236 \\
\hline Cesium Nitrate & $\mathrm{CsNO} 3$ & 0.024 \\
\hline Lead Nitrate & $\mathrm{Pb}\left(\mathrm{NO}_{3}\right)_{2}$ & 0.085 \\
\hline Magnesium Nitrate & $\mathrm{Mg}\left(\mathrm{NO}_{3}\right)_{2} \bullet 6 \mathrm{H}_{2} \mathrm{O}$ & 0.057 \\
\hline Potassium Nitrate & $\mathrm{KNO}_{3}$ & 19.221 \\
\hline Silver Nitrate & $\mathrm{AgNO}_{3}$ & 0.026 \\
\hline Zinc Nitrate & ${\mathrm{Zn}\left(\mathrm{NO}_{3}\right)_{2} \bullet 6 \mathrm{H}_{2} \mathrm{O}}_{0.046}$ \\
\hline Sodium Chloride & $\mathrm{NaCl}$ & 14.984 \\
\hline Sodium Fluoride & $\mathrm{NaF}^{2}$ & 0.420 \\
\hline Sodium Chromate & $\mathrm{Na}_{2} \mathrm{CrO}_{4}$ & 4.205 \\
\hline Sodium Sulfate & $\mathrm{Na}_{2} \mathrm{SO}_{4}$ & 1.140 \\
\hline Potassium Molybdate & $\mathrm{K}_{2} \mathrm{MoO}_{4}$ & 0.204 \\
\hline Aluminum Trihydroxide & $\mathrm{Al}_{2}\left(\mathrm{OH}_{3}\right.$ & 114.77 \\
\hline Sodium Hydroxide & $\mathrm{NaOH}_{3}$ & 196.68 \\
\hline Selenium Dioxide & $\mathrm{SeO}_{2}$ & 0.001 \\
\hline Sodium meta-Silicate & $\mathrm{Na}_{2} \mathrm{SiO}_{3} \bullet 9 \mathrm{H}_{2} \mathrm{O}$ & 2.135 \\
\hline Sodium Phosphate & $\mathrm{Na}_{3} \mathrm{PO}_{4} \bullet 12 \mathrm{H}_{2} \mathrm{O}$ & 2.281 \\
\hline Sodium Carbonate & $\mathrm{Na}_{2} \mathrm{CO}_{3}$ & 22.149 \\
\hline Sodium Nitrate & $\mathrm{NaNO}_{3}$ & 209.70 \\
\hline Sodium Nitrite & $\mathrm{NaNO}_{2}$ & 166.48 \\
\hline Water & $\mathrm{H}_{2} \mathrm{O}$ & 669.37 \\
\hline
\end{tabular}

The challenge simulant was prepared without the organic fraction, which was somewhat opaque. This allowed unobstructed observation of the resin and resin bed, as the simulant is quite transparent. During the experiment, the resin did not show any degradation. 


\section{LAB-RPT-12-00002 R1}

\subsection{PERTECHNETATE}

Pertechnetate was obtained from the Oak Ridge High Flux Isotope Reactor as ammonium pertechnetate. The material was solubilized, and appropriate dilutions were carried out and confirmed using a Perkin Elmer Elan DRC-e model inductively coupled plasma-mass spectrometer (ICP-MS).

For the column tests, a standard curve was generated using a Ludlum Model 2929 dual scaler (Sweetwater, TX), Figure 1. The standard curve was generated by comparing the $5 \mathrm{~min}$ averaged and background-corrected counts to the analyses obtained using the ICP. The matrix for the standard curve was the $6.5 \mathrm{M}$ Na matrix used for the Purolite ${ }^{\circledR}$ A530E ion exchange resin challenge.

For the resin test, a sample of $200 \mathrm{uL}$ of column effluent at progressive BVs was pipetted onto smear pads (Hi-Q Environmental Products Company, part number FP1441-20), allowed to dry, and subjected to $5 \mathrm{~min}$ counts, twice for each sample. The average of the two $5 \mathrm{~min}$ counts was background corrected and compared to the standard curve in Figure 1 to determine the concentration of pertechnetate in the column effluent.

Figure 1. Calibration Curve with Ludlum Model 2929 Dual Scaler.

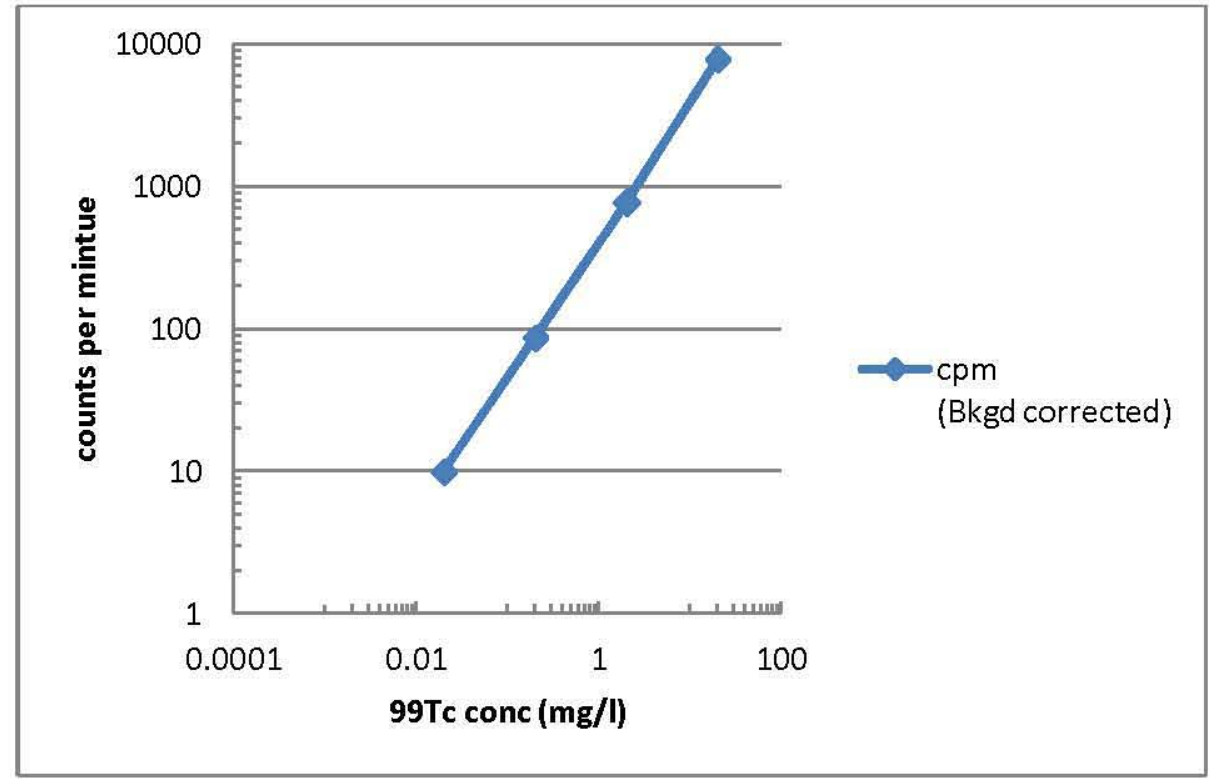




\section{LAB-RPT-12-00002 R1}

\subsection{DISTRIBUTION COEFFICIENT DETERMINATION}

Batch contact tests, using the above simulant spiked with pertechnetate, were conducted to determine distribution coefficients for Purolite ${ }^{\mathbb{B}}$ A530E. The phase ratio was 100:1 (for example, $20 \mathrm{~mL}$ of simulant:0.2 $\mathrm{g}$ of dry basis sorbent), placed on a shaker for $24 \mathrm{hr}$.

The $\mathrm{K}_{\mathrm{d}}$ was determined using Equation 1 (Ion Exchange Theory and Practice, [Harland 2000]):

$$
\mathrm{K}_{\mathrm{A}}{ }^{\mathrm{B}}=\left[\mathrm{C}_{\mathrm{B}}\right]_{\mathrm{r}}\left[\mathrm{C}_{\mathrm{A}}\right]_{\mathrm{s}} /\left[\mathrm{C}_{\mathrm{A}}\right]_{\mathrm{r}}\left[\mathrm{C}_{\mathrm{B}}\right]_{\mathrm{s}}
$$

Where:

$$
\begin{aligned}
& \mathrm{K}_{\mathrm{A}}^{\mathrm{B}}=\text { Distribution coefficient } \\
& {\left[\mathrm{C}_{\mathrm{B}}\right]_{\mathrm{r}}=\text { molar concentration of ion } \mathrm{B} \text { in the resin }} \\
& {\left[\mathrm{C}_{\mathrm{A}}\right]_{\mathrm{S}}=\text { molar concentration of ion } \mathrm{A} \text { in the bulk solution }} \\
& {\left[\mathrm{C}_{\mathrm{A}}\right]_{\mathrm{r}}=\text { molar concentration of ion } \mathrm{A} \text { in the resin }} \\
& {\left[\mathrm{C}_{\mathrm{B}}\right]_{\mathrm{S}}=\text { molar concentration of ion } \mathrm{B} \text { in the bulk solution }}
\end{aligned}
$$

\subsection{PUROLITE ${ }^{\circledR}$ A530E ION EXCHANGE RESIN}

The Purolite ${ }^{\circledR}$ A530E resin specifications (Purolite ${ }^{\circledR}$ A530E Strong Base Anion Macroporous Ion Exchange Resin, "Purolite," Product Data Sheet,) are presented in Table 2.

Table 2. Purolite ${ }^{\circledR}$ A530E Product Data.

\begin{tabular}{|l|l|}
\hline \multicolumn{2}{|c|}{ Basic Features } \\
\hline Application & Perchlorate and Pertechnetate Removal \\
\hline Polymer Structure & $\begin{array}{l}\text { Macroporous polystyrene crosslinked with } \\
\text { divinylbenzene }\end{array}$ \\
\hline Appearance & Spherical Beads \\
\hline Functional Group & Quaternary Ammonium \\
\hline Ionic Form as Shipped & Chloride \\
\hline \multicolumn{2}{|c|}{ Product Information } \\
\hline Total Capacity, Chloride Form & 0.6 eq/L \\
\hline Moisture Retention, Chloride Form & $50-57 \%$ \\
\hline Mean Diameter & $725 \pm 125 \mu \mathrm{m}$ \\
\hline Uniformity Coefficient & 1.7 \\
\hline Specific Gravity & 1.4 \\
\hline Temperature Limits, Chloride Form & $100^{\circ} \mathrm{C}$ \\
\hline pH limits, Stability & $0-14$ \\
\hline
\end{tabular}

Before use, the resin was washed with distilled water in an upflow configuration to remove fines. The washing was stopped when the water overflowing the column contained no visible discoloration from fines, etc. 


\section{LAB-RPT-12-00002 R1}

The resin was subjected to the $10 \mathrm{M} \mathrm{Na}$ simulant over a period of 24 days. Figures 2, 3, and 4 show the resin as received (time $=0$ ), at 7 days in $10 \mathrm{M} \mathrm{Na}$ simulant, and at 24 days in $10 \mathrm{M} \mathrm{Na}$ simulant, respectively.

Figure 2. Purolite A530E at Time Zero in 10 M Sodium Simulant.

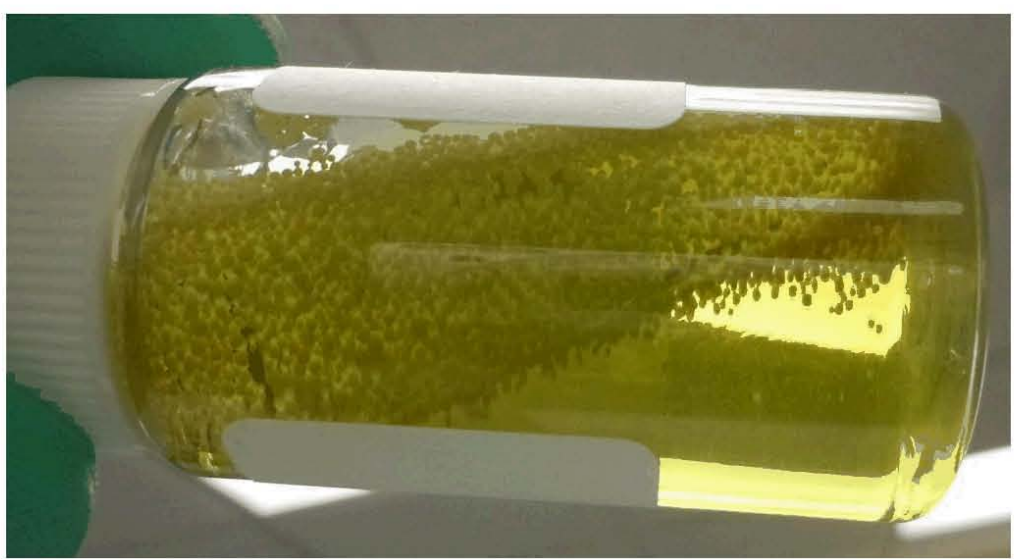

Figure 3. Purolite A530E at 7 Days in 10 M Sodium Simulant.

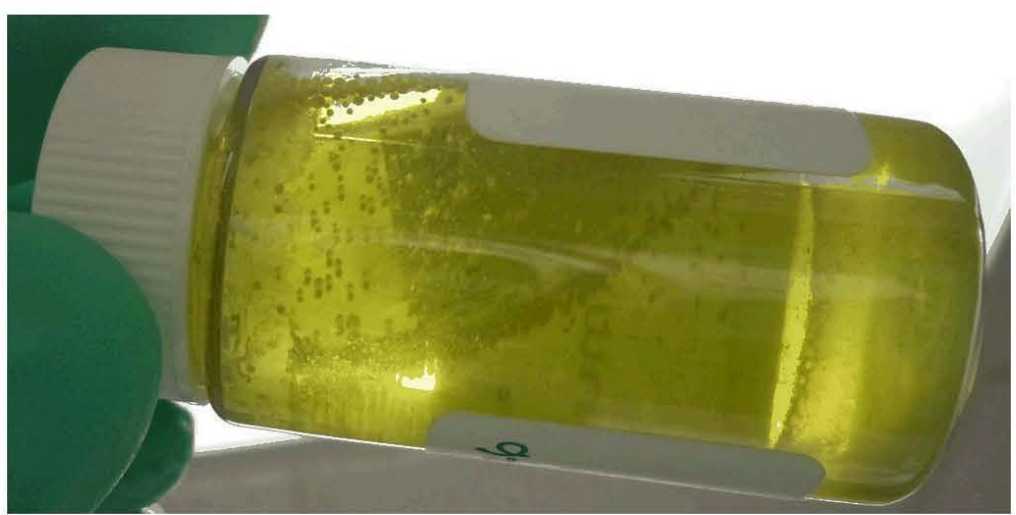


LAB-RPT-12-00002 R1

Figure 4. Purolite A530E at 24 Days in 10 M Sodium Simulant.

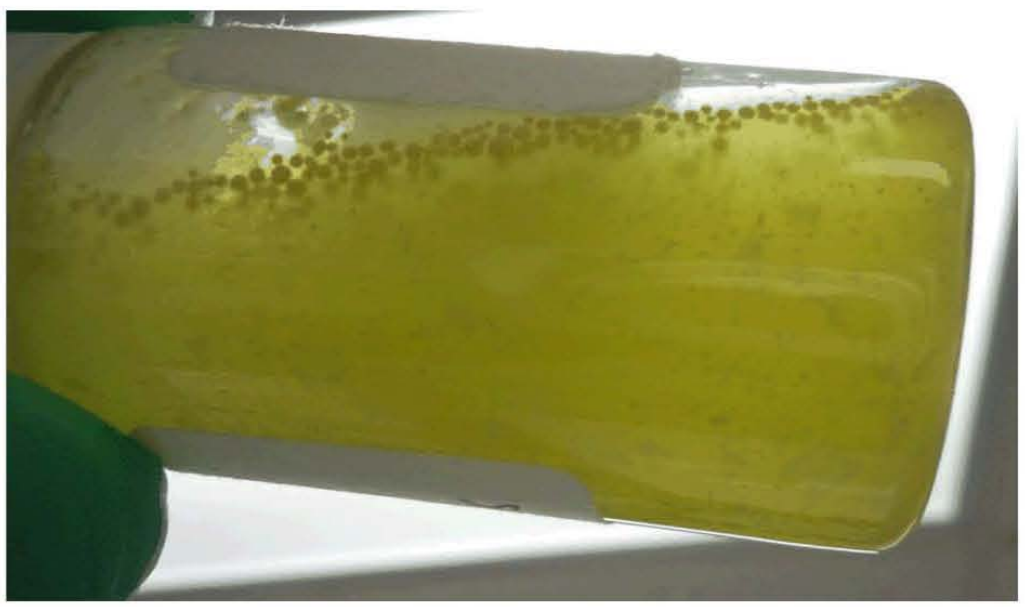

As can be visually determined, there is an apparent degradation of the resin. This degradation was not observed during the column run with $6.5 \mathrm{M}$ sodium (Section 3.2) which was 188 hours ( 7.8 days). This observation bears further investigation as to the robustness of the resin, the degradation products, and the pertechnetate holding capacities at various tank and processing sodium molarities.

\subsection{ION EXCHANGE COLUMNS}

The ion exchange columns were Kontes ${ }^{\circledR 3}$ Flex-Column ${ }^{\circledR 4}$ glass columns with a diameter of $1.5 \mathrm{~cm}$ and a length of $20 \mathrm{~cm}$. A flow adapter was fitted to the column to ensure uniform delivery of spiked simulant to the resin bed in a downward flow configuration.

The resin was backwashed to remove the fines by expanding the bed volume with a sufficient velocity of water to maintain the expanded bed while the fines washed out. The resin was slurried into the ion exchange columns to attain $1 \mathrm{BV}$ at $11 \mathrm{~mL}$ resin. The resin was then classified by placing the pump in an upflow configuration and allowing the bed to expand to approximately two times its depth. The pump was turned off and the valve closed, allowing the resin to settle and produce a classified bed.

The resin did exhibit buoyancy at the sodium molarity of 6.5. The flow adapter enabled the bed to adhere to a constrained geometry during the experiment.

The simulant was delivered using a Masterflex ${ }^{\circledR 5}$ peristaltic pump, calibrated to deliver $22 \mathrm{ml} / \mathrm{hr}$ $(2 \mathrm{BV} / \mathrm{hr})$. Particulates in the simulant feedstock container were filtered in line using a glass wool filter.

\footnotetext{
${ }^{3}$ Kontes is a registered trademark of the Kontes Glass Company, Vineland, New Jersey.

${ }^{4}$ Flex-Column is a registered trademark of the Kontes Glass Company, Vineland, New Jersey.

${ }^{5}$ Masterflex is a registered trademark of the Cole-Parmer Instrument Company, Vernon Hills, Illinois.
} 


\section{LAB-RPT-12-00002 R1}

\section{RESULTS}

\subsection{DISTRIBUTION COEFFICIENTS}

Table 3 shows the $\mathrm{K}_{d}$ as a function of sodium molarity. The $\mathrm{K}_{d} \mathrm{~s}$ were determined at 10 and diluted to $7.5 \mathrm{M}$ and $5 \mathrm{M}$ sodium concentrations.

Table 3. Distribution Coefficients for Tank 241-AN-105.

\begin{tabular}{|c|c|}
\hline Tank 241-AN-105 [Na] & $\begin{array}{c}\text { Distribution Coefficient }\left(\mathbf{K}_{\mathbf{d}}\right) \\
\mathbf{m L} / \mathbf{g}\end{array}$ \\
\hline 5 & 2300 \\
\hline 7.5 & 1987 \\
\hline 10 & 984 \\
\hline
\end{tabular}

Figure 2 shows the distribution coefficients exhibited by the A530E resin over time when challenged with AN-105 simulant at $6.5 \mathrm{M}$ sodium. Sampling intervals for the time-based $\mathrm{K}_{d}$ testing were $7.5,15,30,60,120$, and 240 minutes. The regression equation for the response curve is:

$$
\text { y estimate }=-0.0057 \times 2+6.0365 x+18.796
$$

Figure 5. Distribution Coefficients versus Contact Time.

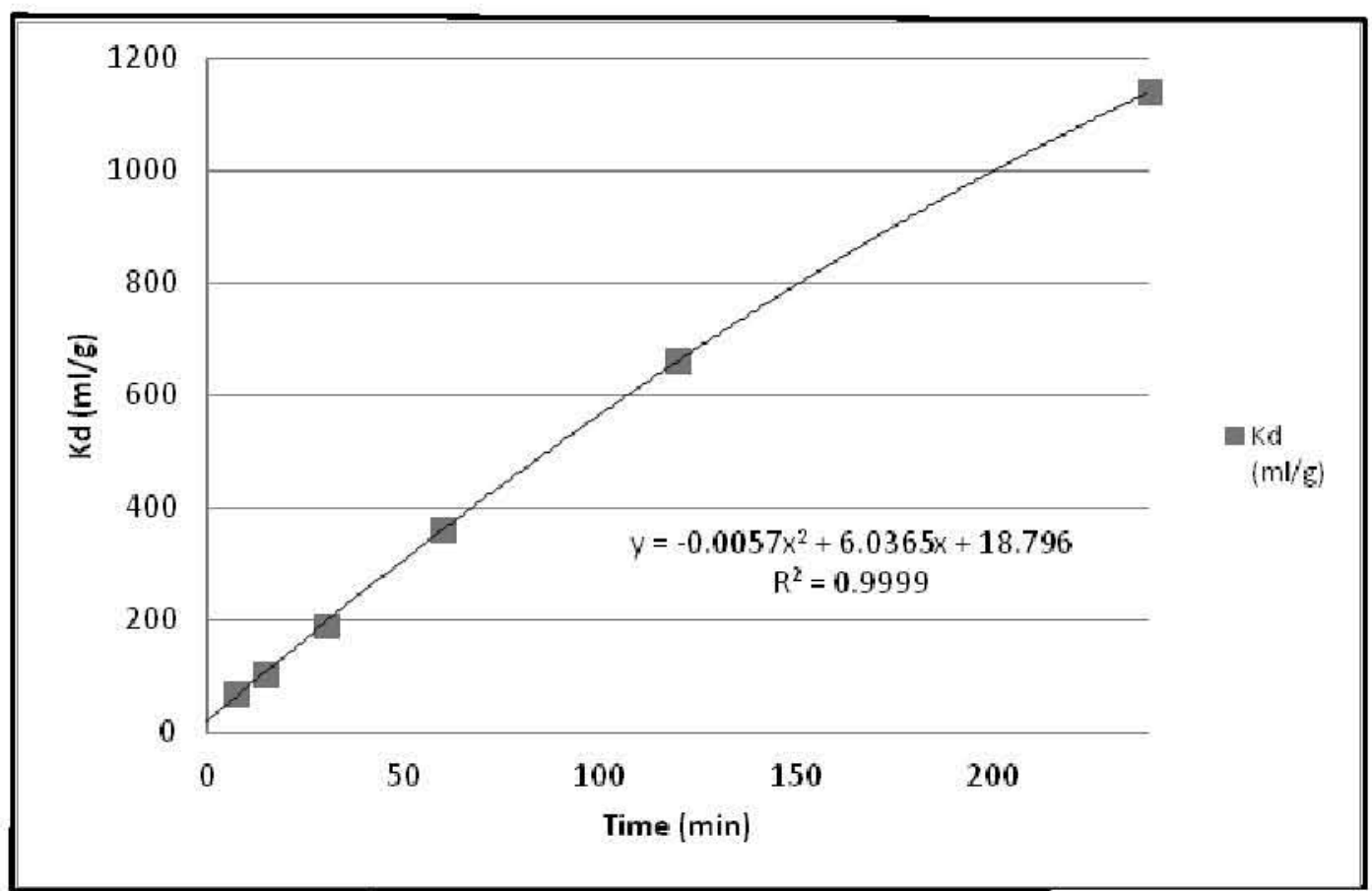


A sorption curve was obtained by sampling at time intervals of $7.5,15,30,60,120$, and $240 \mathrm{~min}$ (Figure 3 ). The response equation is:

$$
\text { y estimate }=0.1551 \ln (\mathrm{x})+0.1098
$$

Figure 6. Pertechnetate Sorbed onto A530E from AN-105 Simulant at 6.5 M Sodium.

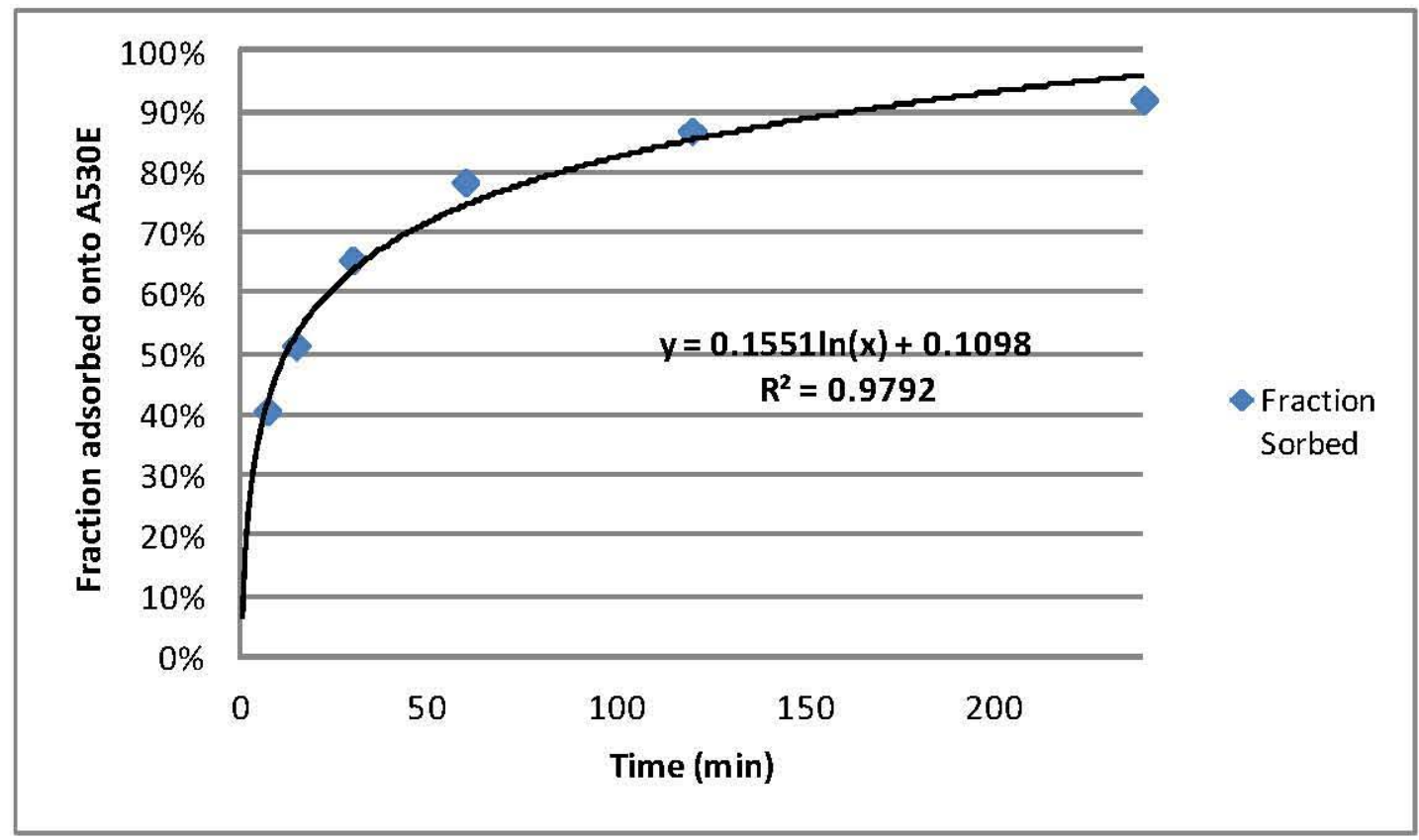

The lambda value, which is obtained by Equation 4, is an estimation of the bed volumes to breakthrough $\left(\mathrm{C} / \mathrm{C}_{0}=0.5\right)$ and is a function of the distribution coefficient and resin density (BNF-003-98-0219, Small-Scale Ion Exchange Removal of Cesium and Technetium from Hanford Tank 241-AN-102).

$$
\lambda=\left(\mathrm{K}_{\mathrm{d}}\right)(\rho)=\mathrm{BV} \text { to breakthrough (unit less) }
$$

Using this parameter, the associated BVs to breakthrough were calculated as shown in Table 4.

Table 4. Lambda Calculated Bed Volumes to Breakthrough $\left(C / C_{0}=0.5\right)$.

\begin{tabular}{|c|c|c|}
\hline $\begin{array}{c}\text { Distribution } \\
\text { Coefficient }\left(\mathbf{K}_{\mathbf{d}}\right) \\
\mathbf{m L} / \mathbf{g} \\
\mathbf{N a ]}\end{array}$ & $\begin{array}{c}\text { Resin Density } \\
\mathbf{N a}\end{array}$ & $\begin{array}{c}\text { Lambda Calculated BV } \\
\text { to } \\
\mathbf{C} / \mathbf{C}_{\mathbf{0}}=\mathbf{0 . 5}\end{array}$ \\
\hline $2300[5]$ & 1.4 & 3220 \\
\hline $1987[7.5]$ & 1.4 & 2781 \\
\hline $984[10]$ & 1.4 & 1377 \\
\hline
\end{tabular}




\section{LAB-RPT-12-00002 R1}

\subsection{COLUMN EXPERIMENT}

The columns, pump, filter, and sampling points were configured as depicted in Figure 7.

Figure 7. Column Test Configuration.

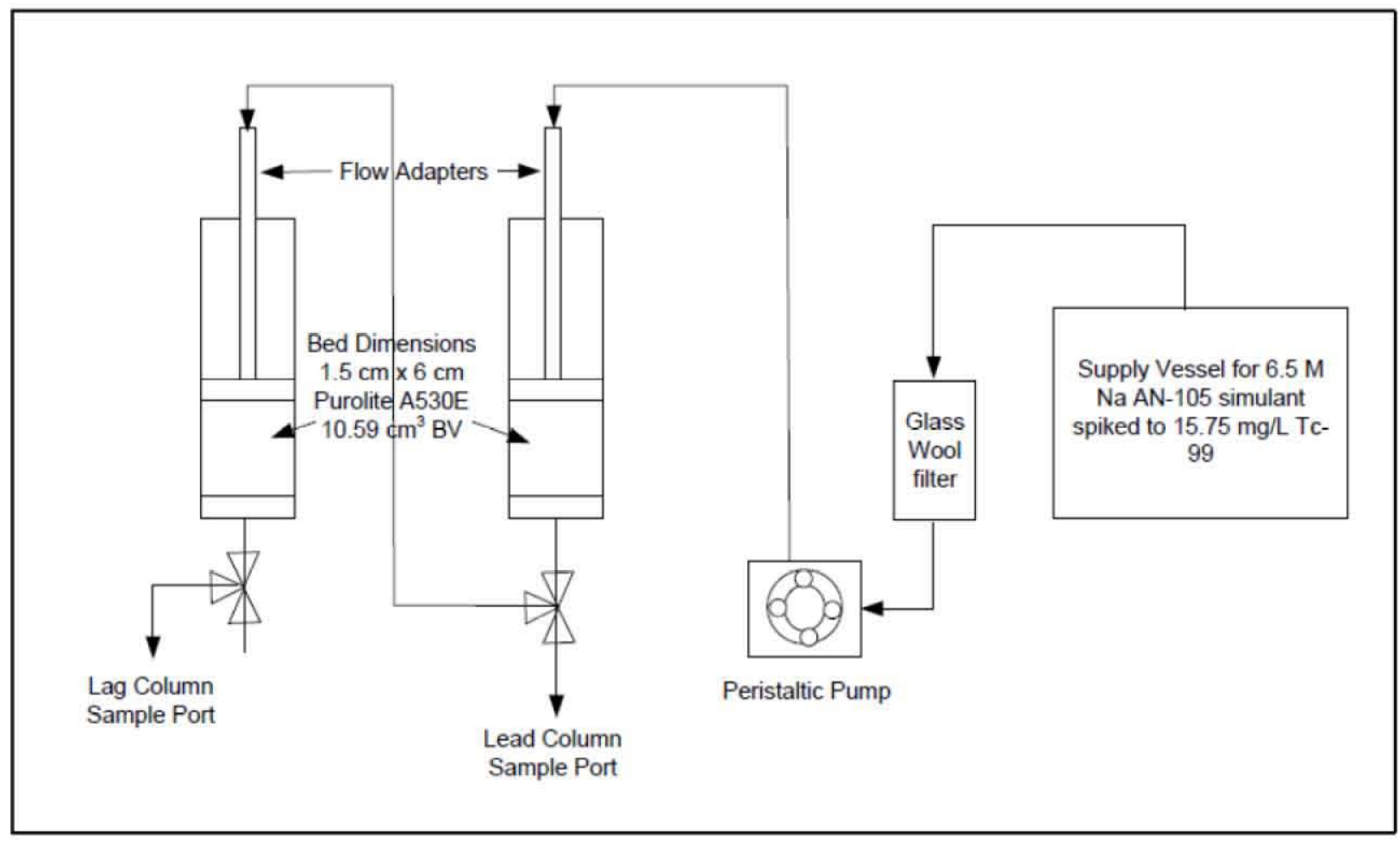

Samples were taken over a $188 \mathrm{hr}$ run time. The lead column was at a $\mathrm{C} / \mathrm{C}_{0}$ of 0.98 when the run was halted due to the exhaustion of pertechnetate-spiked $\mathrm{AN}-105$ simulant. Figure 8 shows the breakthrough curve, with $\mathrm{C} / \mathrm{C}_{\mathrm{o}}=0.5$ at $284 \mathrm{BV}$ at $156 \mathrm{hr}$. 
Figure 8. Breakthrough Curve for the Lead Column.

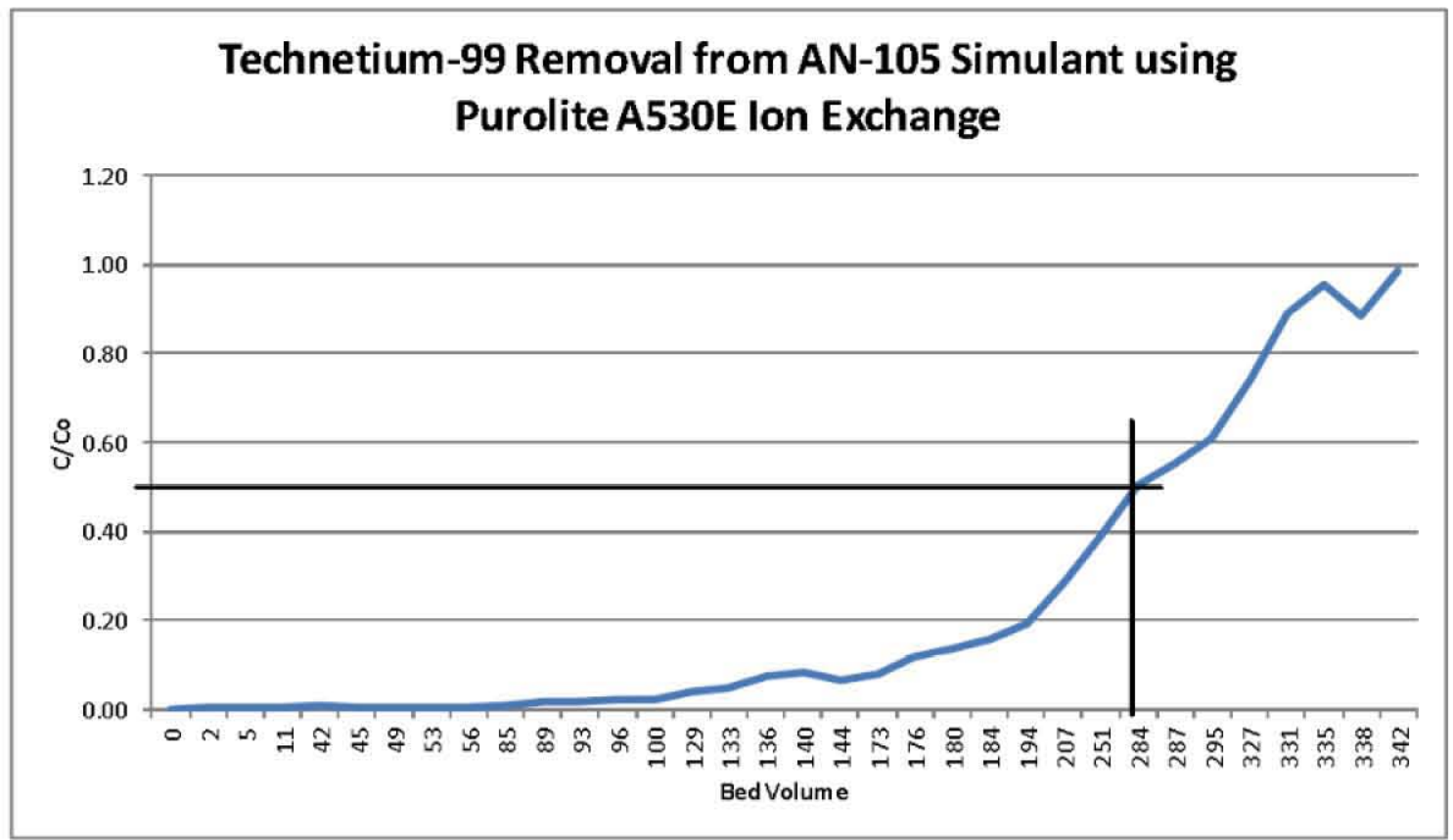

The test was terminated at $342 \mathrm{BV}$ due to the exhaustion of the AN-105 technetium-spiked simulant and the exhaustion of the supply of pertechnetate.

The lag column never achieved a $\mathrm{C} / \mathrm{C}_{0}$ of more than 0.01 during the test.

Appendix A contains the matrix of bed volumes and $\mathrm{C} / \mathrm{C}_{0}$ that apply to the breakthrough curve.

\section{DISCUSSION}

The Purolite ${ }^{\circledR}$ A530E was successful in removing pertechnetate from a supernate simulant for tank 241-AN-105 at $6.5 \mathrm{M}$ sodium. The resin should be considered as a candidate in the technetium management effort. Over the course of the run, no visual degradation of the resin was apparent.

There is a definite matrix influence on the resin performance as evidenced by the distribution coefficient as a function of sodium molarity. As evidenced by the breakthrough at $284 \mathrm{BV}$ versus the calculated $\lambda$, Table 4 , it is evident that a matrix effect overrides this simplified approach to calculated breakthrough. 


\section{LAB-RPT-12-00002 R1}

If the Purolite ${ }^{\circledR}$ A530E is to be used with undiluted tank supernate or with dissolved tank solids, further testing needs to be carried out, such as:

- Column configurations

- Leaching of sorbed pertechnetate from resin under environmental conditions

- Effects of long term exposure at sodium and $\mathrm{pH}$ levels of interest

- Sequestration of spent resin into Cast Stone as a final waste form

It is recommended that testing using Hanford double-shell tank waste be carried out in a hot cell environment.

\section{REFERENCES}

ANSI/ANS-16.1-2003, Measurement of the Leachability of Solidified Low-Level Radioactive Wastes by a Short-term Test Procedure, American Nuclear Society, La Grange Park, Illinois.

BNF-003-98-0219, 2000, Small-Scale Ion Exchange Removal of Cesium and Technetium from Hanford Tank 241-AN-102, Westinghouse Savannah River Company, Aiken, South Carolina.

DE-AC27-01RV14136, Waste Treatment Plant Contract, Section C, "Statement of Work," Modification 147 (M147), December 11, 2000, Bechtel National, Inc., Richland, Washington.

Gu, B., G. M. Brown, P. V. Bonnesen, L. Liang, B. A. Moyer, R. Ober, and S. D. Alexandratos, 2000, "Development of Novel Bifunctional Anion-Exchange Resins with Improved Selectivity for Pertechnetate Sorption from Contaminated Groundwater," Environ. Sci. Technol, Vol. 34, pp. 1075-1080.

Harland, C. E., 1994, Ion Exchange Theory and Practice, $2^{\text {nd }}$ Edition, Royal Society of Chemistry, Cambridge, United Kingdom.

LAB-PLN-11-00010, 2011, Evaluation of Technetium Ion Exchange Material against Hanford Double Shell Tank Supernate Simulate with Pertechnetate, R0, Washington River Protection Solutions LLC, Richland, Washington.

ORP-11242, 2011, River Protection Project System Plan, R6, United States Department of Energy, Office of River Protection, Richland, Washington.

Purolite ${ }^{\circledR}$ A530E Strong Base Anion Macroporous Ion Exchange Resin, "Purolite," Product Data Sheet, 2010, The Purolite Company, Bala Cynwyd, Pennsylvania. 


\section{LAB-RPT-12-00002 R1}

Radiological and Chemical Fact Sheets to Support Health Risk Analyses for Contaminated Areas, "Technetium," 2005, Argonne National Laboratory, Argonne, Illinois.

RPP-RPT-23199, 2004, The Removal of Technetium-99 from the Effuent Treatment Facility Basin 44 Waste Using Purolite A-53OE, Reillex HPQ, and Sybron IONAC SR-7 Ion Exchange Resins, R0, CH2MHILL Hanford Group, Richland, Washington.

RPP-RPT-39195, 2009, Assessment of Technetium Leachability in Cement-Stabilized Basin 43 Groundwater Brine, R1, Washington River Protection Solutions LLC, Richland, Washington.

UCRL-JRNL-212334, 2005, Current Status of the Thermodynamic Data for Technetium and its Compounds and Aqueous Species, Lawrence Livermore National Laboratory, Livermore, California.

WSRC-TR-2000-00338, 2001, Hanford Waste Simulants Created to Support the Research and Development on the River Protection Project - Waste Treatment Plant, Westinghouse Savannah River Company, Aiken, South Carolina. 
LAB-RPT-12-00002 R1

\section{APPENDIX A}

Lead Column Response 
LAB-RPT-12-00002 R1

Appendix A

Table A-1. Lead Column Response, $\mathrm{C} / \mathrm{C}_{0}$ versus Bed Volumes.

\begin{tabular}{|c|c|}
\hline BV & C/Co \\
\hline 0 & 0.00 \\
\hline 2 & 0.01 \\
\hline 5 & 0.00 \\
\hline 11 & 0.00 \\
\hline 42 & 0.01 \\
\hline 45 & 0.00 \\
\hline 49 & 0.00 \\
\hline 53 & 0.00 \\
\hline 56 & 0.01 \\
\hline 85 & 0.01 \\
\hline 89 & 0.02 \\
\hline 93 & 0.02 \\
\hline 96 & 0.02 \\
\hline 100 & 0.02 \\
\hline 129 & 0.04 \\
\hline 133 & 0.05 \\
\hline 136 & 0.07 \\
\hline 140 & 0.08 \\
\hline 144 & 0.06 \\
\hline 173 & 0.08 \\
\hline 176 & 0.12 \\
\hline 180 & 0.14 \\
\hline 184 & 0.16 \\
\hline 194 & 0.19 \\
\hline 207 & 0.28 \\
\hline 251 & 0.39 \\
\hline 284 & 0.50 \\
\hline 287 & 0.55 \\
\hline 295 & 0.61 \\
\hline 327 & 0.74 \\
\hline 331 & 0.89 \\
\hline 335 & 0.95 \\
\hline 338 & 0.89 \\
\hline 342 & 0.98 \\
\hline & \\
\hline
\end{tabular}




\section{Electronically Approved by:}

UserName: Duncan, James (h0079048)

Title: APD Chemist

Date: Wednesday, 20 June 2012, 12:35 PM Pacific Time

Meaning: Approved by the author or delegate

UserName: Russell, Rose (h5476814)

Title:

Date: Wednesday, 20 June 2012, 01:58 PM Pacific Time

Meaning: Approved by the customer or delegate

UserName: Seidel, Cary (h0009079)

Title: APD Manager

Date: Thursday, 21 June 2012, 11:12 AM Pacific Time

Meaning: Approved by the Group Manager or delegate 